\title{
Article
}

\section{Public Perception of Wilderness in Iceland}

\author{
Rannveig Ólafsdóttir *(i) and Anna Dóra Sæpórsdóttir[D \\ Department of Geography and Tourism Studies, Faculty of Life and Environmental Sciences, University of \\ Iceland, 102 Reykjavík, Iceland; annadora@hi.is \\ * Correspondence: ranny@hi.is; Tel.: +354-525-5482
}

Received: 4 February 2020; Accepted: 24 March 2020; Published: 27 March 2020

\begin{abstract}
In recent years, there has been a gradually growing emphasis on the protection of wilderness in Iceland. This is highlighted in the current preparation of a new national park in the Icelandic central highlands, which will become Europe's largest national park. However, in order to protect the wilderness, a mutual understanding, both on what it is and where it is, is needed. This paper seeks to evaluate Icelanders' perception and understanding of wilderness. Furthermore, to assess the value of wilderness for the Icelandic public and determine what lies behind the valuation, an online survey aided by maps from Google Earth and photographic scenarios of different landscapes was sent out to a nationally representative sample of Icelanders. The survey respondents mapped their perceived scope of Icelandic wilderness and furthermore chose between several landscape scenarios they thought most and least suited to their perception of wilderness. The results show that nearly all land located above the $300 \mathrm{~m}$ elevation line is perceived as wilderness, reflecting the country's uninhabited highlands areas. The results also show that for the general public in Iceland it is chiefly an open and vast landscape, uninhabited areas, and the absence of anthropogenic features that bestow an area with the status of wilderness. The results demonstrate that any sign of anthropogenic interference, aside from archaeological remains, decrease Icelanders' perception of wilderness. Moreover, despite being mostly categorized as urbanists or neutralists according to the purism scale, the majority of Icelanders still consider services, such as petrol stations, hotels, shops, restaurants, and diverse leisure services, along with energy production, to negatively impact the value of wilderness. Most Icelanders thus seem to regard wilderness as a valuable asset from the economic, cultural, and environmental perspectives, which underscores its uniqueness.
\end{abstract}

Keywords: wilderness; wilderness value; public perception; Iceland

\section{Introduction}

The value of wilderness seems to be increasing across the globe, partially because an ever increasing number of tourists are interested in visiting such locations, but also due to the fact that there are steadily fewer wilderness areas in existence, which increases the value of those left. Hence, an economic argument is being employed to a greater degree to rectify the preservation of wilderness. However, the debate regarding the concept of wilderness and its definition has been ongoing for a long time and a number of reports and articles have been written on the subject without resulting in a concerted international definition [1-4], thus demonstrating the controversy and complexity of the concept. In recent years there has been a gradually growing emphasis on the protection of wilderness in public discourse in Iceland. This is highlighted in various governmental operations, such as the country's Nature Conservation Act and the National Planning Policy, as well as in the preparation of a new highland national park that is estimated to cover about one third of Iceland's land surface [5].

Iceland is an island located in the middle of the North Atlantic Ocean and situated on the Mid-Atlantic Ridge. It is characterized by dynamic landscape, which influences the country's wild 
character and subsequently its wilderness. Iceland is the most sparsely populated country in Europe, with only about 360,000 inhabitants on an island of $103,000 \mathrm{~km}^{2}$, or 3.5 persons $/ \mathrm{km}^{2}$ [6]. The sparse population has throughout the ages mainly been located along the coastline, leaving the interior highlands an uninhabited wilderness. The whole of Iceland is believed to have been uninhabited until about 1200 years ago when the first Norse settlers arrived into a landscape dominated by pristine nature. The settlers and their descendants' land uses, such as grazing and utilization of the natural woodlands, triggered land degradation that has accelerated over the centuries, intensified by poor natural resource management (e.g., [7-9]). Until recently, the interior highlands were only used for summer grazing. This changed in the early 1970s when the highlands' remoteness was broken with improved accessibility following construction of the first hydro-electrical power plant to be located in the country's highlands [10-13]. Since then Iceland's central highlands have witnessed a rapid expansion towards multiple uses, which have gradually altered the state of the highland terrain. Hence, energy production and tourism, along with grazing, have steadily grown in scope. These industries require much land surface and they come with infrastructure and other disturbances, which are very noticeable in the Icelandic open landscape, thus affecting the experience of those passing through.

Conventional definitions of wilderness, such as the US Wilderness Act from 1964, stress the natural state of the environment, the absence of human habitation and the lack of other human related influences and impacts [14]. In Iceland the official definition of the concept was recently updated in a new Act on Nature Conservation, No. 60/2013 [15]. It resembles the conventional ones defining wilderness (article 5, paragr. 19) to be an area of land:

- that is at least $25 \mathrm{~km}^{2}$ in size, or such that one can enjoy solitude and the natural landscape without disturbance from human structures or traffic resulting from mechanized vehicles.

- that is situated at a distance of at least $5 \mathrm{~km}$ from human structures and other technical traces, such as power lines, power plants, dams, and constructed roads.

The importance of wilderness in Icelandic nature is emphasized in a specific section dedicated to wilderness protection (Article 46). Therein, it is stated that: "Vast land areas where traces of human interference are barely noticeable and the natural landscape develops without any pressure related to human influences can be protected as wilderness ... ; The declaration of protection shall aim towards preserving the characteristics of the area, e.g., by upholding a diverse and spectacular landscape, open field of vision, and/or protecting large integral ecosystems, and to ensure that present and coming generations can enjoy solitude and nature in these areas without disruption from infrastructure or motorized vehicle traffic".

The largest dispute on the wilderness concept worldwide however argues that wilderness as a place reflects principally anthropogenic values and human perception [16-21]. Therefore, more and more definitions now take into account people's perception of wilderness. Currently, the Icelandic government's strategies for sustainable development stress that the endurance of vast continuous wilderness in the country's uninhabited areas should be assured [22]. In Iceland's first planning strategy on a national scale, made for the years 2015-2026, the emphasis on the protection of wilderness is increased, especially when it comes to the planning of the country's central highlands, where Iceland's largest wilderness areas can be found [22-24]. In the national planning strategy it is furthermore stated that the municipalities which are adjacent to the country's central highlands should devise a policy on the protection of wilderness in their own planning strategies, as well as research the possibility for re-wilding areas. Despite a legal definition, this might be problematic as peoples' understanding and perception on what is wilderness still seems to vary. This paper aims to evaluate Icelanders' perception of wilderness and the value of wilderness for the Icelandic public by: (i) mapping the scope and distribution of wilderness in Iceland based on Icelanders public perception and understanding of wilderness, (ii) identifying which attributes in the Icelandic landscape contribute the most to Icelanders wilderness perception, and (iii) identifying the importance of wilderness in the mind of Icelanders and what types of infrastructure are considered appropriate without decreasing the quality of their perceived wilderness. 


\section{Icelandic Wilderness Mapping}

Iceland lacks a strong tradition for wilderness mapping and limited research exists on the subject. The first attempt at mapping Icelandic wilderness was carried out by the Environment Agency of Iceland following the passing of Act on Nature Conservation No. 44/1999 [25], where the definition of wilderness was first presented in Icelandic law. This mapping was updated in 2009 and based on available digital geodata, which was limited at that time, especially as regards spatial distribution of power lines. The next attempt was conducted by Ólafsdóttir and Runnström [10] who based their mapping on internationally recognized methods. Their mapping took thus into account remoteness from motorized access, permanent settlements, and signs of technological infrastructure, such as power lines, power plants and reservoirs. Digital geodata from the IS50v National Land Survey of Iceland database was gathered, as well as from other institutes, while the coordinates for analog data were digitized. The data was further categorized according to traffic density, size of settlements and the type of technological traces and the distances (from $0.5-5 \mathrm{~km}$ ) for each category were calculated. They tested two types of mathematical models, i.e., distance analysis, which is based on the mapping of areas that are at a certain distance from an infrastructure (Figure 1A), and viewshed analysis, which is based on the mapping of areas free from visual impact of infrastructure (Figure 1B). Their results indicate that wilderness covers around $30 \%$ of Iceland's total area, and thereof a third is covered by glaciers.

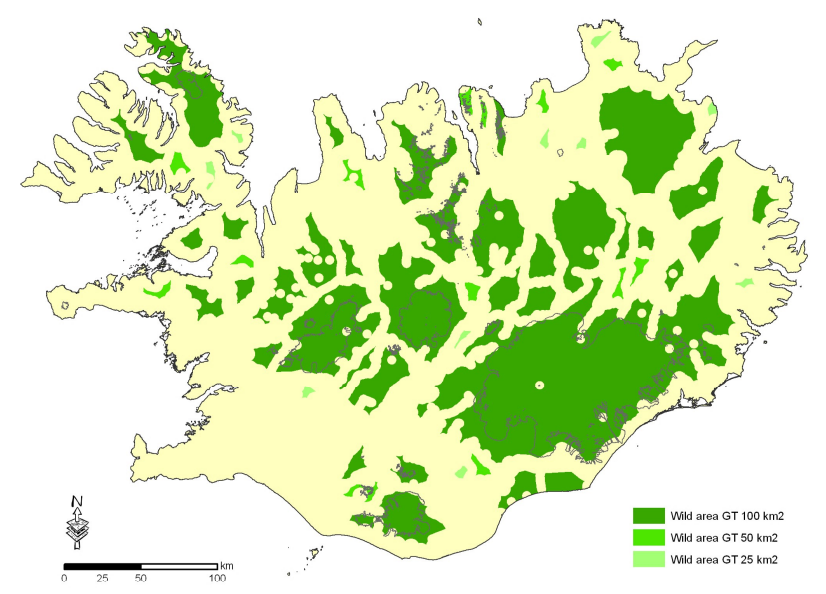

(A)

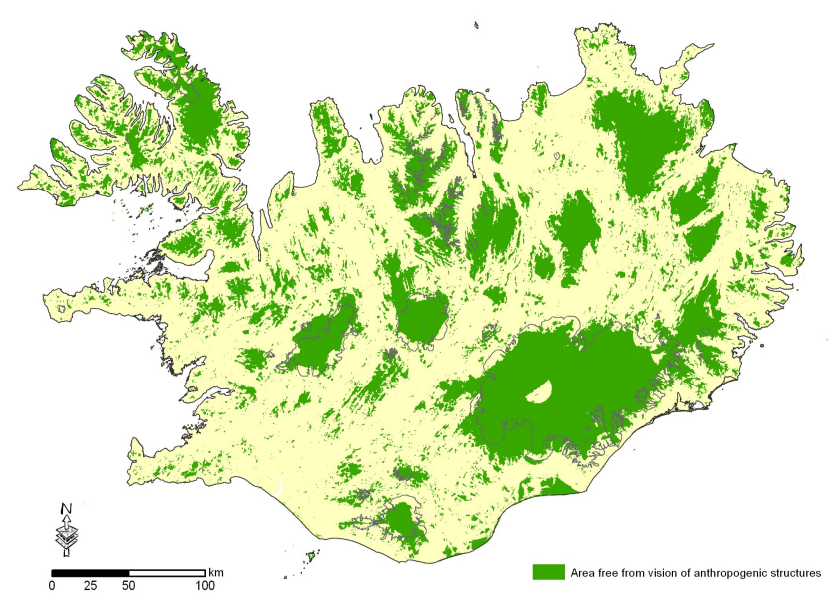

(B)

Figure 1. Wilderness mapping from Ólafsdóttir and Runnström based on the definition of Icelandic wilderness according to Act no. 44/1999 on nature conservation. (A) shows calculation based on a distance analysis and (B) calculation based on a viewshed analysis [10,15]. 
The quality of wilderness is often evaluated based on the scope of the total wilderness area, i.e., the larger the area the higher the quality of the wilderness [4]. This is reflected in many of the legal definitions of wilderness, which are largely based on their size. The largest wilderness areas in Iceland are on and around glaciers in the central highlands. The construction of roads, and other anthropogenic infrastructure, during the past decades has gradually reduced these areas. A study on the changes in land areas without impact from roads and power lines from 1936-2010 [26] shows that in 1936 almost the entire central highlands were free from the impact of roads and power lines, or 93\% of the total area, which then formed a continuous wilderness area. Three quarters of a century later, or in 2010, this area had diminished to $21 \%$ of the central highlands' total area (Figure 2). Focusing on wilderness mapping in the Vatnajökull National Park in Eastern Iceland, Tims [27] added new variables into the previous wilderness modelling, which were meant to capture some of the subjective aspects of wilderness. These variables are cell phone coverage, car traffic intensity, and geotagged photographs taken by tourists and shared online (Figure 3A,B). His results indicate that the geotagged photographs are a useful way to show the distribution of tourist numbers, and where the number is the highest and lowest. This variable, i.e., number of people, has a great impact on whether people will experience solitude without interruptions, which is an important part of the wilderness definition in the Icelandic nature conservation act. The distribution of cell phone coverage serves as an indicator of areas where people are able to travel without assistance or a support network. The amount of traffic is furthermore a more accurate indicator of the impact of roads and access on wilderness experience than merely the remoteness from roads. His results thus reveal that the perception of wilderness quality is lowest in areas with the highest rates of visitation.

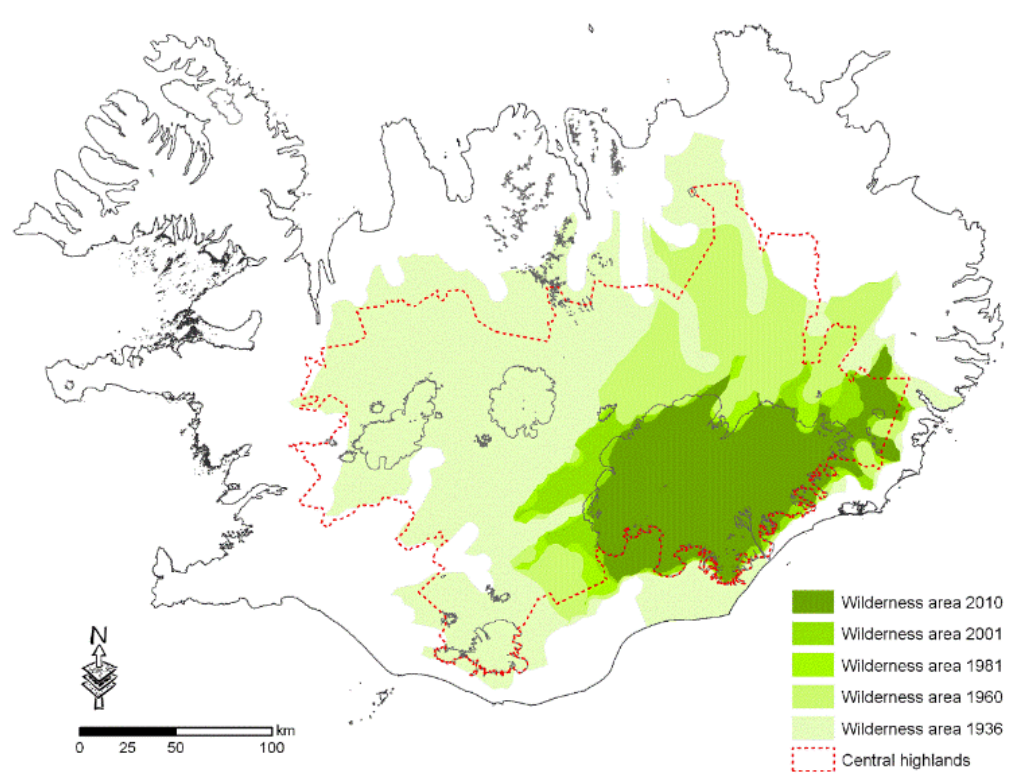

Figure 2. Changes in the scope of the largest total wilderness area in the Icelandic central highlands from 1936-2010 (modified from [28,29]). 

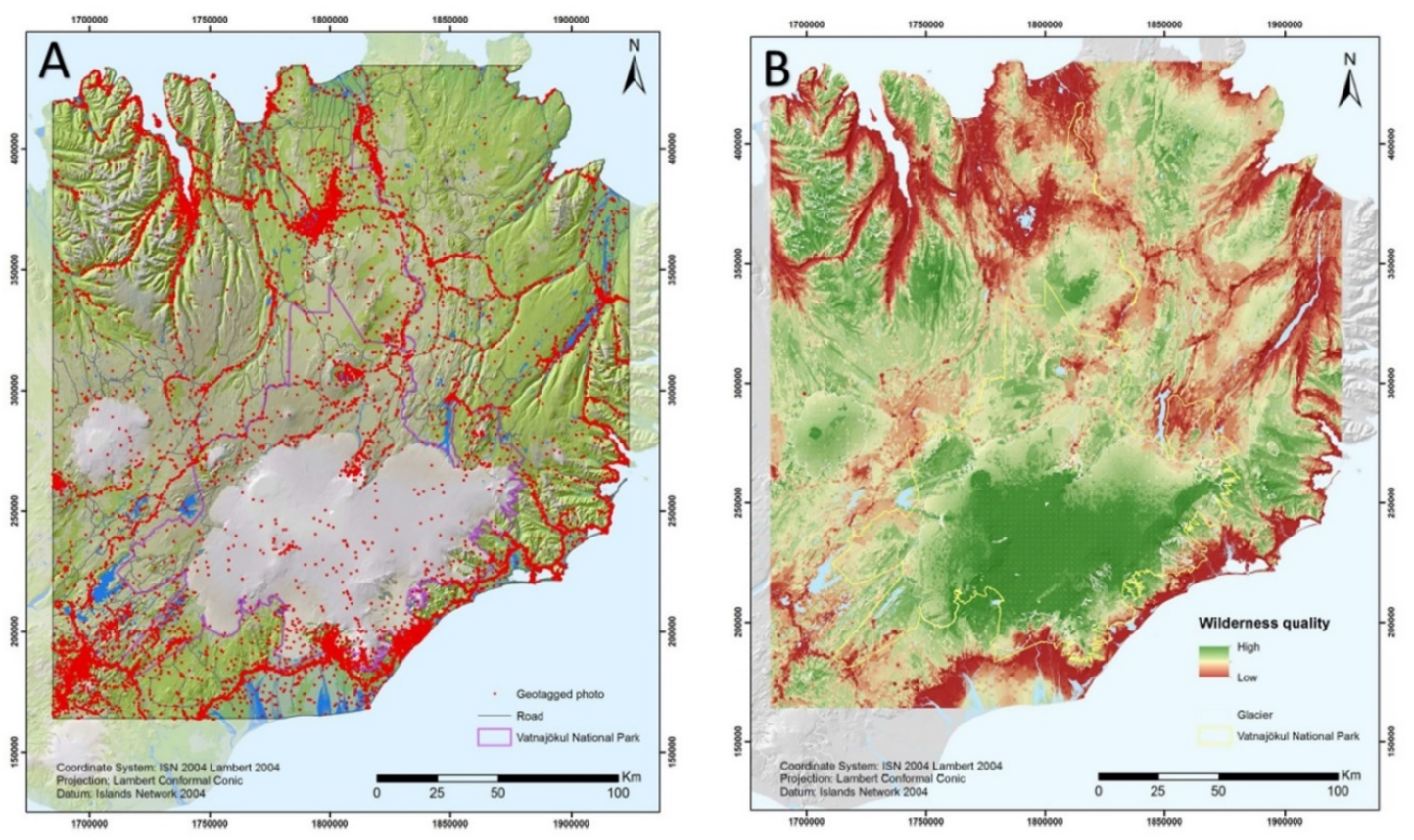

Figure 3. (A) The distribution of web-shared geotagged photographs taken by tourists in the eastern part of Iceland. (B) Wilderness map over the same area. Vatnajökull National Park is delineated by a yellow line [27].

One of the reasons why it has been difficult to agree on a definition of the wilderness concept is that the boundary between man-made and natural environment is often unclear and perceived differently between individuals [19-22]. Accordingly, as an alternative approach, it has become more common to take people's perception into consideration when mapping wilderness [23-28]. The first attempt to map wilderness based on perception in Iceland was a mapping of tourists' experience of wilderness in the Icelandic southern highlands [17]. This mapping is based on the premise of the purism scale, which divides tourists into four groups according to their different perception towards the environment [29]. On one end of the scale are strong purists, who seek experiencing nature in its most natural state and want next to no service. Following them are moderate purists who also wish to experience nature, although they care less about it being in its most natural state. Next there are neutralists, who require rather good infrastructure and services, and are not highly sensitive when it comes to disturbances to the environment. Then, on the other end of the scale are non-purists, or urbanists, who want good infrastructure, high service levels, and are not sensitive to disturbances to the environment, or the number of other tourists. The results indicate that urbanists experience, more or less, the entire southern highlands as wilderness, while for purists less than half of the area is wilderness (Figure 4). Numerous studies have been conducted worldwide to evaluate the experience of tourists towards wilderness and their reasons for visiting such areas (e.g., [12,30-34]). Individuals' experience and perception of wilderness is dependent on many factors, such as their cultural and social background [35]. Furthermore, how people assess the value of wilderness is dependent on location, as well as the circumstances of each period. Nevertheless, many studies show that the most common reason behind the decision to visit a wilderness area is to be away from the crowds and city life's hustle and bustle, and to experience simplicity and unspoiled nature (e.g., [3,4]). 


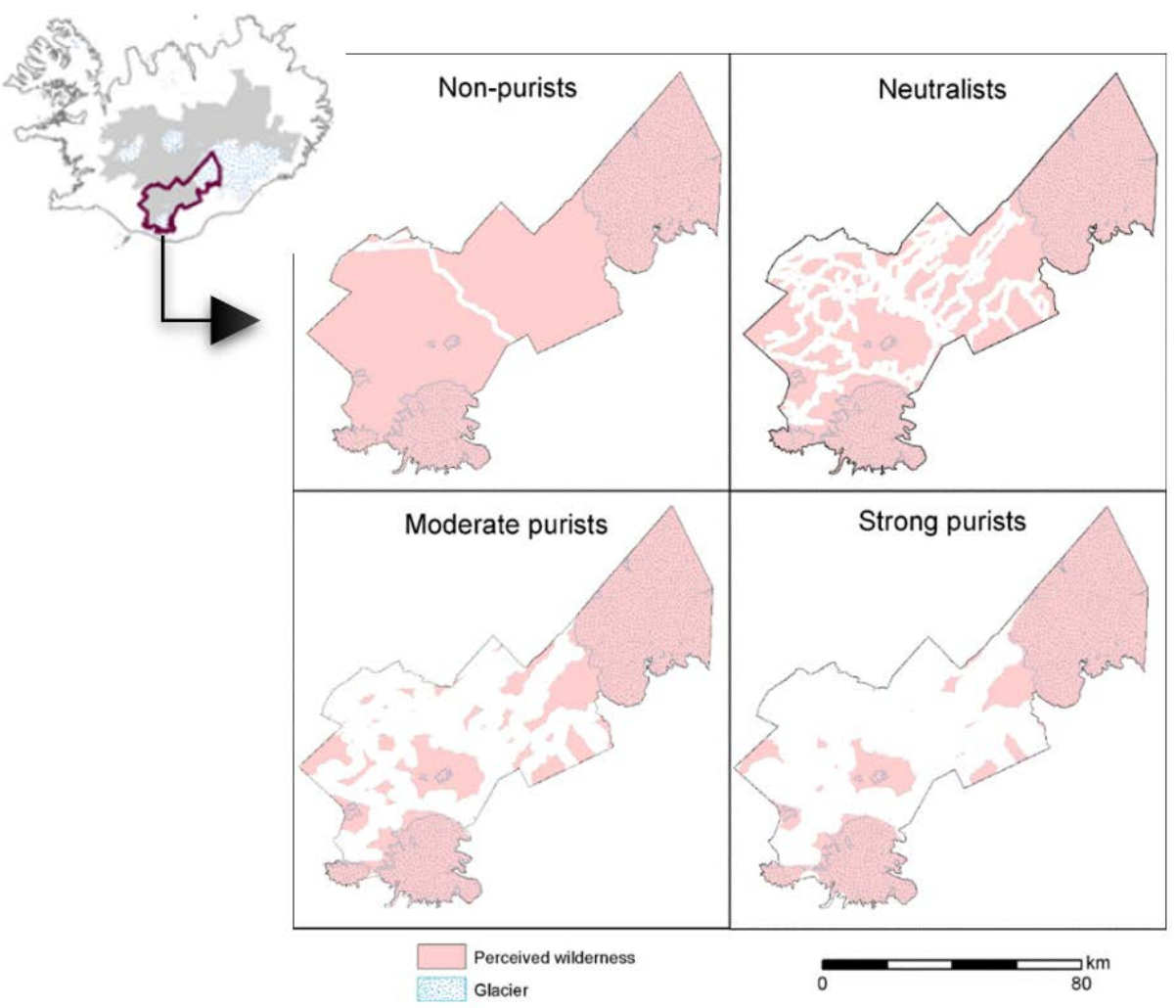

Figure 4. Tourists' experience of wilderness in the Icelandic southern highlands [11].

The most recent mapping of Icelandic wilderness was conducted by Árnason, et al. [36], whose goal was to develop a new methodology to assess wilderness in the country's central highlands according to the official definition of wilderness in the Icelandic Nature Conservation Act no. 60/2013 [15]. Their mapping is primarily based on four types of infrastructure, i.e., buildings, roads, reservoirs, and power lines, and different distances are calculated for each type (Figure 5). The principal difference from previous mapping lies in the more detailed sub-categorization of buildings, depending on the nature of the buildings. They also employ a more simplified categorization of roads, but according to the updated definition of the wilderness concept in Act no. 60/2013 only constructed roads should be taken into account. That excludes all mountain roads and tracks that are numerous in the Icelandic central highlands, many laid by the pioneers and explores who were the first to drive into the highlands between the 1930s and 1950s [13]. Still, it is clear that there is considerable traffic on many mountain roads in the highlands, especially those leading to the most popular tourist destinations, such as to Landmannalaugar [37], and it is doubtful that one can enjoy solitude and nature there without any disturbances from motorized vehicles, as the regulation stipulates. 


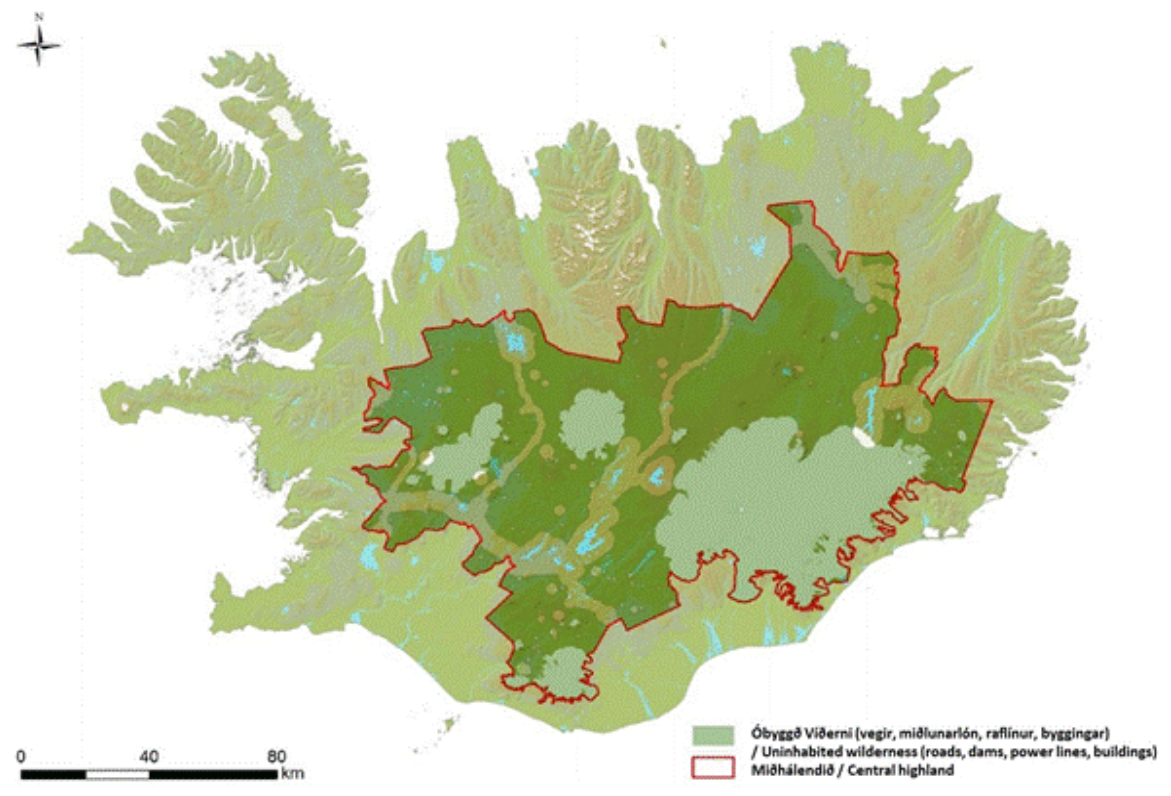

Figure 5. Wilderness mapping from Árnason, et al. [36] based on the definition of wilderness according to Act No. 60/2013 on nature protection. The dark green color represents the mapped wilderness areas within the Icelandic central highlands, and the blue green color represent ice caps.

Hence, despite the short tradition of wilderness mapping in Iceland, quite a few mapping attempts already exist. These attempts however show that mapping wilderness is by no means a straight forward thing to carry out, which makes wilderness mapping a great challenge. As emphasized in the Icelandic current act on nature conservation [15] wilderness is a vital part of Iceland's unique and diverse landscape. In order to protect wilderness it is critical to know where it is, but also what it is in the minds of the Icelandic public, and whether they perceive wilderness as a thing of value. Otherwise, there will not be a consensus regarding its preservation.

\section{Methods}

To evaluate Icelanders' perception and understanding of wilderness an online survey, supported by maps from Google Earth and photographic scenarios of wilderness, was sent out to a nationally representative sample of the Icelandic public in the spring of 2016. In order to obtain a representative sample, a request was made to the University of Iceland's Social Science Research Institute to send out the survey through its online panel, which includes individuals who are randomly selected from the Icelandic National Register and reflect the composition of the population in terms of age, gender and residence. Therefore, based on the results of their online panel surveys, it is possible to generalize about people's attitude to the issues in question. The survey was sent to 2199 members of the online panel during the 8-22nd of April 2016. In total, 641 responses were obtained, which makes the response rate $30 \%$. This relatively low response rate could be explained by the fact that the panel respondents were not accustomed to the method used in the survey which required them to do some online mapping and view photographic scenarios. In addition, it took quite some time to complete the whole survey. Still, a sample size of over 640 was considered a sufficient base to continue the work. After weighting the sampled data according to gender, age, education and residence the results are considered to be generalizable to the Icelandic public.

The survey questionnaire was divided into three parts. In the first part, the aim was to map the scope and distribution of wilderness according to the Icelandic publics' understanding of wilderness. The survey respondents were asked to mark on a map the location of areas they considered to be wilderness. In this part of the survey a software called Map-me, which in this study was based upon 
using Google Earth, was used. This made it possible for the survey respondents to sit at home while they did virtual travel around the country. The Map-me software is based on the fuzzy ideology and the outputs are in the form of fuzzy cognitive maps [38]. The cognitive map in this case reflects on how and where the survey respondents perceive wilderness in Iceland and thereby shows their "mental landscape" of wilderness. However, the mapping of phenomena such as wilderness can be hard due to the fuzziness of the concept, and it can thus be difficult for people to draw sharp lines around the phenomena, and sometimes even impossible. Therefore, the Map-me software uses a spray-can instead of sharp lines when people map the phenomena. The spray-can makes it possible for the respondents to create areas with unclear borderlines as the spray dots spread randomly around their perceived boarders instead of creating a sharp line. Each dot that an individual sprays on the map is put into a database marked with the coordinate of the dot, the scale the participant used when he/she sprayed the dot, IP number of the computer, and other information [39,40]. When processing the collected dots, they were converted into continuous surfaces based on their density. This provided information on the number of dots per $\mathrm{km}^{2}$ (Figure 6).

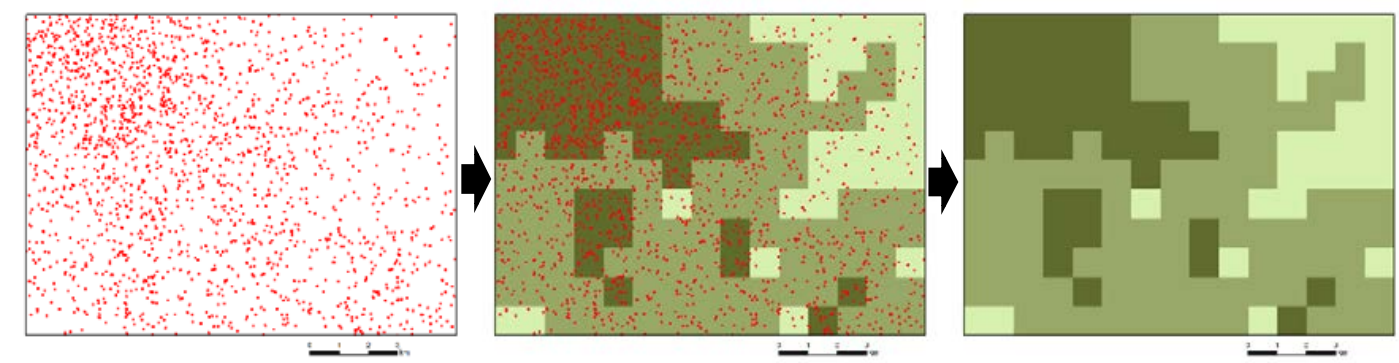

Figure 6. Dot coverage converted into a continuous surface by density of dots, where the darkest surface shows the highest density of dots.

Before the respondents started to map wilderness in the survey, they were given the opportunity to practice their skill to use the spray-can and zoom in and out on Iceland in Google Earth. When done with their mapping, they were asked in an open-ended question about what makes an area a wilderness. Answers to this question were varied, but after encoding, ten major themes emerged that reflect the most common responses.

In the second part of the survey, the focus was on Icelanders' perception towards wilderness. An attempt was made to calculate a wilderness value, which was based on respondents' evaluation of different photographic supported scenarios. A Scottish survey from 2012, concerning the perception of the Scottish public towards wilderness, was used as a foundation for this part of the survey [41]. The aim of the Scottish survey was, on the one hand, to increase knowledge of the public's perception of Scottish wilderness, and, on the other hand, to utilize that knowledge as a variable into further mapping of the Scottish wilderness. Their survey was based on the following four key attributes: (i) the naturalness of the land cover and wildlife; (ii) the presence of man-made structures and features; (iii) the remoteness from roads; (iv) the terrain. These attributes are similar to the ones that have been used to map wilderness and assessing wilderness quality in many countries $[16,17,42]$. To assess the public's view of these attributes, the Scots created 25 scenarios, each of which is made up of several statements referring to the above four key attributes. Each statement was accompanied by a photo card containing several photographs to demonstrate the statement [41]. Numerous scholars (e.g., [43,44]) stress the benefits of using photo-elicitation to gain access to respondents' perceptions and values and placing them in a position of self-awareness. Hence, in this part of the survey the perception of the survey respondents was evaluated with respect to the aforementioned four key attributes to calculate a wilderness score for Iceland using best-worst scaling technique. A total of 26 scenario statements were used based on the model of the Scots, but adapted to Icelandic conditions and the aims of this study. Each statement was thus adjusted to Icelandic circumstances and presented with a photo card 
with a few photographs (Figure 7). Due to the large number of photographs, each respondent received five scenario questions, (photo card with statement) which were randomly distributed between them. They were then asked to choose the statements they thought most and least compatible with their experience of wilderness. Based on this it was calculated which statement was considered the most or least descriptive of the respondents' perception of wilderness. Wilderness scores were then calculated, showing which statements the respondents generally perceived as the most and least descriptive of wilderness. The wilderness score was calculated so that in the first scenario question, the respondent sees all five descriptions A, B, C, D and E. If he selects A as the description that best describes his perception of wilderness and $C$ as the one that describes it the worst, description $A$ is given a value 2 but description $C$ is given a value -2 . Three descriptions then remain to be decided upon by the participant. The next question therefore contains these three descriptions, B, D, and E. If the respondent selects $B$ as the description that best describes his perception of wilderness, and $\mathrm{E}$ as the one that describes his perception the worst, description B will get the value of 1, but description E the value -1 . Thus, information about the ranking of items is obtained for each survey respondent. The calculated wilderness scores provided a criterion for assessing the respondents perceived value of wilderness.
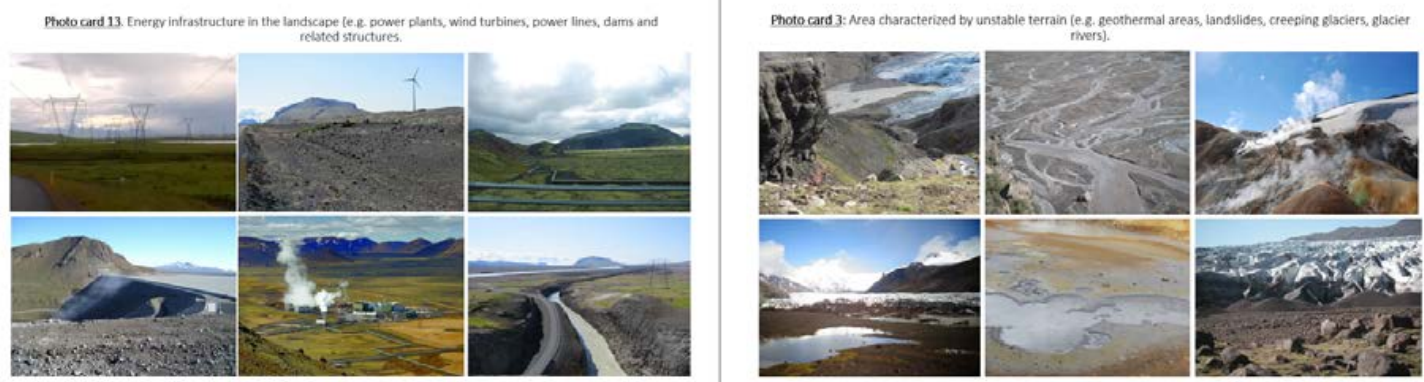

Figure 7. Two examples of photo cards and statements used to describe the 26 landscape scenarios used in the questionnaire survey.

In the third and last part of the survey, the focus was on the importance of wilderness in the mind of the Icelandic public. The survey respondents were asked how important they consider wilderness as a part of Icelandic nature, whether any actions are needed to preserve wilderness, and how important they consider certain infrastructure and service, such as roads, accommodation, etc. when travelling in Icelandic wilderness. The response options were presented on a 5-point Likert scale. The data were weighted according to the background variables, i.e., gender, age, residence, and education, so that the results would be as representative as possible of the sample group of all Icelanders. Principal component analysis was further performed, using rotation method varimax with Kaiser normalization, in order to analyse whether there are underlying patterns. The selection of the number of components was based on scree test and eigenvalues greater than 1 .

\section{Results}

\subsection{Scope and Distribution of Perceived Wilderness}

The results from the Map-me analysis show that nearly all land located above the 300 m elevation line is perceived as wilderness in the mind of the Icelandic public (Figure 8A). Most of it falls within the borders of the uninhabited central highlands (Figure $8 \mathrm{~B}$ ). The respondents' understanding of the wilderness concept is likely to play the largest part in their mapping. When asked in an open-ended 
question about what characteristics combine the areas they mapped as wilderness and what in their mind makes them wilderness, uninhabited areas characterize wilderness in the mind of most respondents. That explains to a large extent the vast coverage of wilderness shown in the mapping, which literally covers all the highlands areas within the country. In the minds of many, wilderness is also an area where there are little human traces. Pristine nature and open spaces are elements that characterize wilderness in the minds of many respondents. Other factors weigh less (Figure 9).
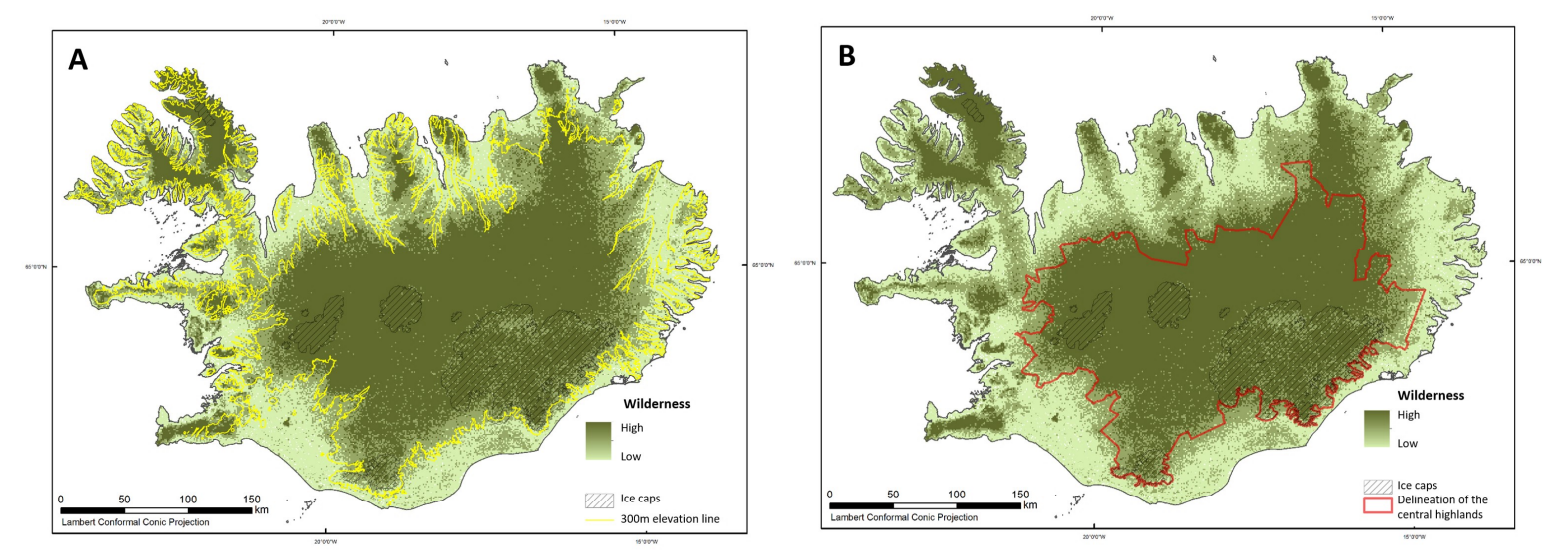

Figure 8. The Map-me results of the scope of perceived wilderness in Iceland compared to the $300 \mathrm{~m}$ elevation line ((A) yellow line), and the central highlands boarders ((B) red line).

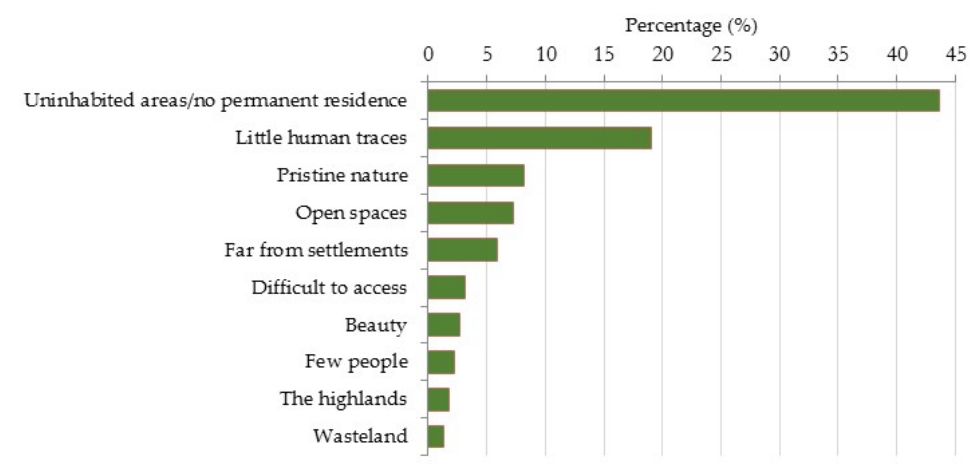

Figure 9. Elements that characterizes areas perceived and mapped as wilderness.

\subsection{Attributes that Contribute the Most to the Icelandic Public's Perception of Wilderness}

The results from the photographic scenarios reveal that uniform landscape, with few distinct landmarks, augments the perception of wilderness the most, i.e., the more open and homogenous the landscape, the stronger the sense of wilderness experience. Furthermore, landscapes without anthropogenic features enhance the respondents' perception of wilderness, and this applies to all types of landscape. The anthropogenic features which decrease the respondents' perception of wilderness the most are inhabited areas (towns and villages), energy constructions, and long linear forms, such as power lines, roads and tracks. Signs of tourism, such as walking paths and mountains huts have less impact on the experience of wilderness (Figure 10; Table 1). Meanwhile, wildlife (such as birds, foxes, seals) increases the experience of wilderness, while domestic animals reduce the experience. 

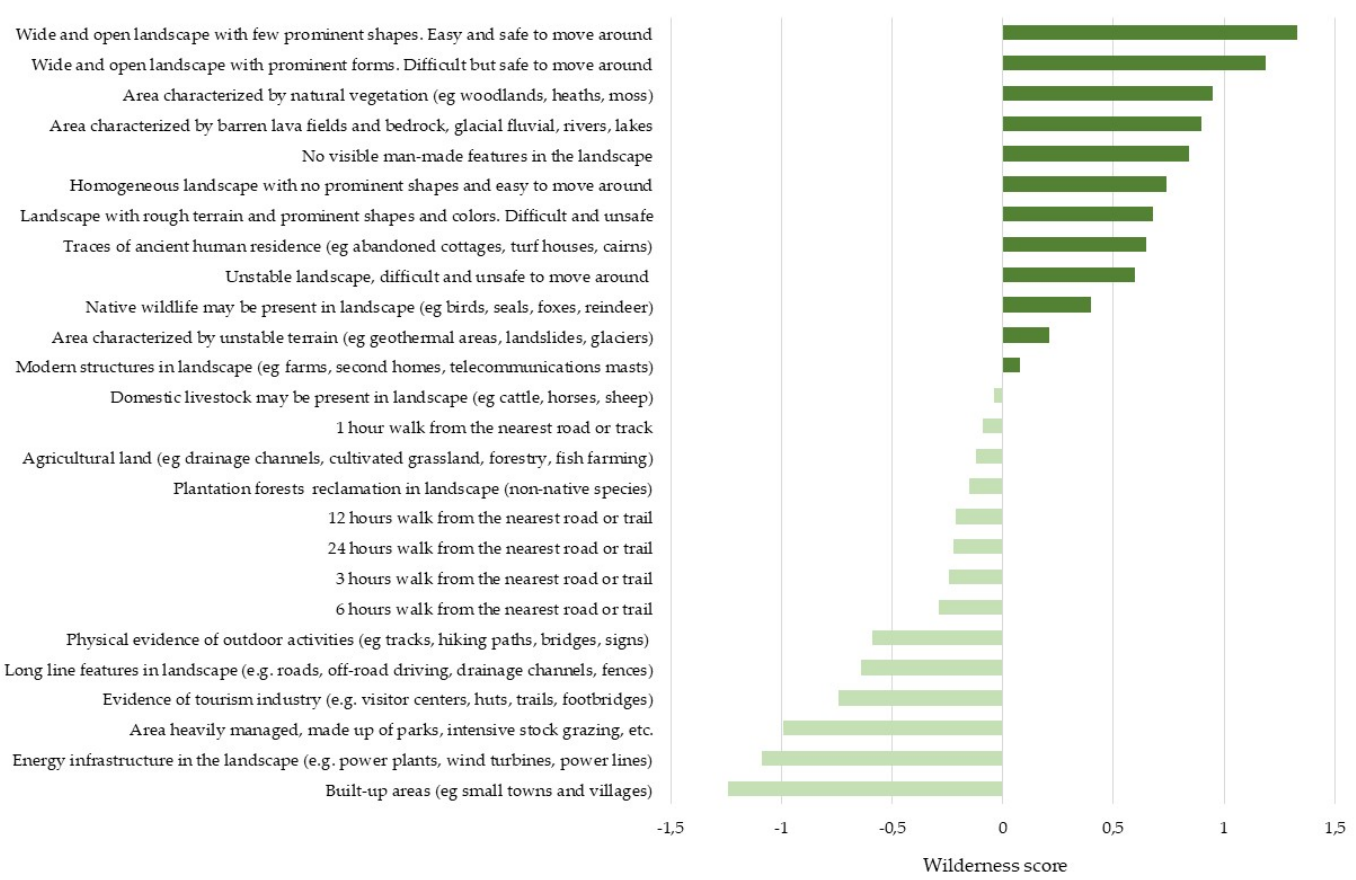

Figure 10. Attributes with positive (dark green) and negative (light green) wilderness scores. The higher the score, the stronger is the perceived wilderness perception. Likewise, the lower the score, the poorer is the perceived wilderness perception.

Table 1. Statements used to describe different landscape scenarios classified according to areas' naturalness, anthropogenic features in nature, fauna, landscape and features, and distances, and calculated wilderness scores.

\begin{tabular}{|c|c|c|}
\hline Photo Card No & $\begin{array}{l}\text { Statements (Presented on Each Photo Card) } \\
\text { Naturalness }\end{array}$ & Wilderness Score * \\
\hline 1 & $\begin{array}{l}\text { Area characterized by natural vegetation (e.g., woodlands, heaths, moss-heaths, } \\
\text { moss covered lava fields) }\end{array}$ & 0.95 \\
\hline 2 & $\begin{array}{l}\text { Area characterized by non-vegetative lava fields, exposed bedrock, glacial } \\
\text { moraines, and glacial fluvial, rivers og lakes }\end{array}$ & 0.90 \\
\hline 3 & $\begin{array}{c}\text { Area characterized by unstable terrain (e.g., geothermal areas, landslides, creeping } \\
\text { glaciers, glacier rivers) }\end{array}$ & 0.21 \\
\hline 4 & $\begin{array}{c}\text { Agricultural land (e.g., drainage channels, cultivated grassland, forestry, grazing, } \\
\text { fish farming) }\end{array}$ & -0.12 \\
\hline 5 & $\begin{array}{c}\text { Area has evidence of tourism industry (e.g., visitor centers, mountain huts, hiking } \\
\text { trails, footbridges, tracks) }\end{array}$ & -0.74 \\
\hline 6 & Area heavily managed, made up of parks, intensive stock grazing, etc. & -0.99 \\
\hline \multicolumn{3}{|c|}{ Anthropogenic features } \\
\hline 7 & No visible man-made features in the landscape & 0.84 \\
\hline 8 & $\begin{array}{l}\text { Traces of human residence from earlier centuries (e.g., abandoned cottages, turf } \\
\text { houses, stone walls and cairns) }\end{array}$ & 0.65 \\
\hline 9 & $\begin{array}{l}\text { Modern built structures in landscape (e.g., farms, summer houses, fences, } \\
\text { telecommunications masts) }\end{array}$ & 0.08 \\
\hline 10 & Plantation forests reclamation in landscape (non-native species) & -0.15 \\
\hline 11 & $\begin{array}{l}\text { Physical evidence of recreation and outdoor activities in landscape (e.g., tracks, } \\
\text { hiking paths, hiking bridges, viewing points, information signs, ski lifts, angling) }\end{array}$ & -0.59 \\
\hline 12 & $\begin{array}{l}\text { Long line features in landscape (e.g., roads, vehicle tracks. off-road driving, } \\
\text { drainage channels, fences) }\end{array}$ & -0.64 \\
\hline 13 & $\begin{array}{l}\text { Energy infrastructure in the landscape (e.g., power plants, wind turbines, power } \\
\text { lines, dams and related structures) }\end{array}$ & -1.09 \\
\hline 14 & Built-up areas (e.g., small towns and villages) & -1.24 \\
\hline
\end{tabular}


Table 1. Cont.

\begin{tabular}{|c|c|c|}
\hline Photo Card No & $\begin{array}{l}\text { Statements (Presented on Each Photo Card) } \\
\text { Fauna }\end{array}$ & Wilderness Score * \\
\hline 15 & Native wildlife may be present in landscape (e.g., birds, seals, foxes, reindeer) & 0.40 \\
\hline 16 & Domestic livestock may be present in landscape (e.g., cattle, horses, sheep) & -0.04 \\
\hline \multicolumn{3}{|c|}{ Landscape and features } \\
\hline 17 & $\begin{array}{l}\text { Wide and open landscape with few prominent shapes, usually easy and safe to } \\
\text { move around }\end{array}$ & 1.33 \\
\hline 18 & $\begin{array}{l}\text { Wide and open landscape with some prominent forms and rather difficult to move } \\
\text { around but safe }\end{array}$ & 1.19 \\
\hline 19 & Homogeneous landscape with no prominent shapes and easy to move around & 0.74 \\
\hline 20 & $\begin{array}{l}\text { Landscape is characterized by rough terrain and many prominent shapes and } \\
\text { colors, is difficult and unsafe to move around }\end{array}$ & 0.68 \\
\hline 21 & $\begin{array}{l}\text { Unstable landscape that is difficult and unsafe to move around (e.g., loose scree in } \\
\text { mountainous areas, high temperature geothermal areas, glacial rivers, glacial } \\
\text { fluvial sediments) }\end{array}$ & 0.60 \\
\hline \multicolumn{3}{|c|}{ Distance } \\
\hline 22 & $1 \mathrm{~h}$ walk from the nearest road or track & -0.09 \\
\hline 23 & $3 \mathrm{~h}$ walk from the nearest road or track & -0.24 \\
\hline 24 & $6 \mathrm{~h}$ walk from the nearest road or track & -0.29 \\
\hline 25 & $12 \mathrm{~h}$ walk from the nearest road or track & -0.21 \\
\hline 26 & $24 \mathrm{~h}$ walk from the nearest road or track & -0.22 \\
\hline
\end{tabular}

By calculating the variation between the highest and lowest value of each of the initial four key attributes, information regarding which of the key attributes influences the perception of wilderness the most can be gathered. Thus, the largest gap shows the most important attribute when it comes to wilderness perception. The results show that the most important aspects stimulating the respondents' perception of wilderness are the 'naturalness of the land cover and wildlife' and the 'presence of anthropogenic structures and features in the landscape'. 'Remoteness from roads' and 'terrain' weigh far less when it comes to Icelanders' perception of wilderness (Figure 11).

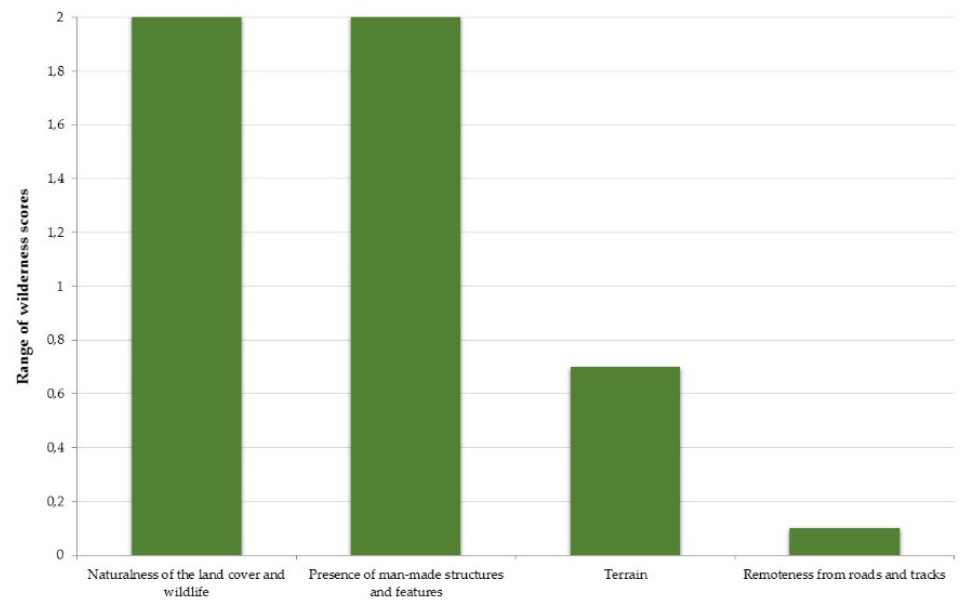

Figure 11. The most important attributes stimulating Icelanders' perception of wilderness calculated as range of wilderness-scores for each attribute scenario.

\subsection{Importance of Wilderness and Appropriate Infrastructure}

To analyze the importance of wilderness in the mind of the Icelandic public and what types of infrastructure are considered appropriate to match that importance, the survey respondents were first asked how important they consider wilderness as a part of Icelandic nature. A vast majority of respondents $(94 \%)$ regard wilderness as very important $(66 \%)$ or important $(28 \%)$. Approximately $70 \%$ think that the Icelandic wilderness is at risk, while $30 \%$ believe this is not the case. Those who consider 
wilderness to be at risk were also asked about the actions they consider important in order to reduce the risk. The majority consider it important to bring about efficient tourism management (83\%), limit the development of power plants (63\%), designate wilderness as a specific conservation area in regulations $(60 \%)$, and limit the construction of power lines and radio masts (58\%). Other attributes weigh less (Figure 12). Principal component analysis identified two components which together explain 56.1\% of the total variance in the answers (Table 2). The first factor seems to be measuring restricting actions towards anthropogenic transformation. Respondents scoring high on this component in general think it to be important to limit the construction of power plants, power lines, and transmission towers, limit tourism services and the making of new tracks as well as re-wilding areas by for example removing anthropogenic structures, reducing the number of roads and tracks, eliminating alien species, reducing grazing and restoring natural vegetation. This first factor explains about $42 \%$ of the total variance of the variables. The second component consisted of respondents who prefer more efficient management actions based on research and planning, such as designation of wilderness as areas for special protection in Icelandic law, and the establishment of efficient management as regards grazing, tourism, forestry, and fishing.

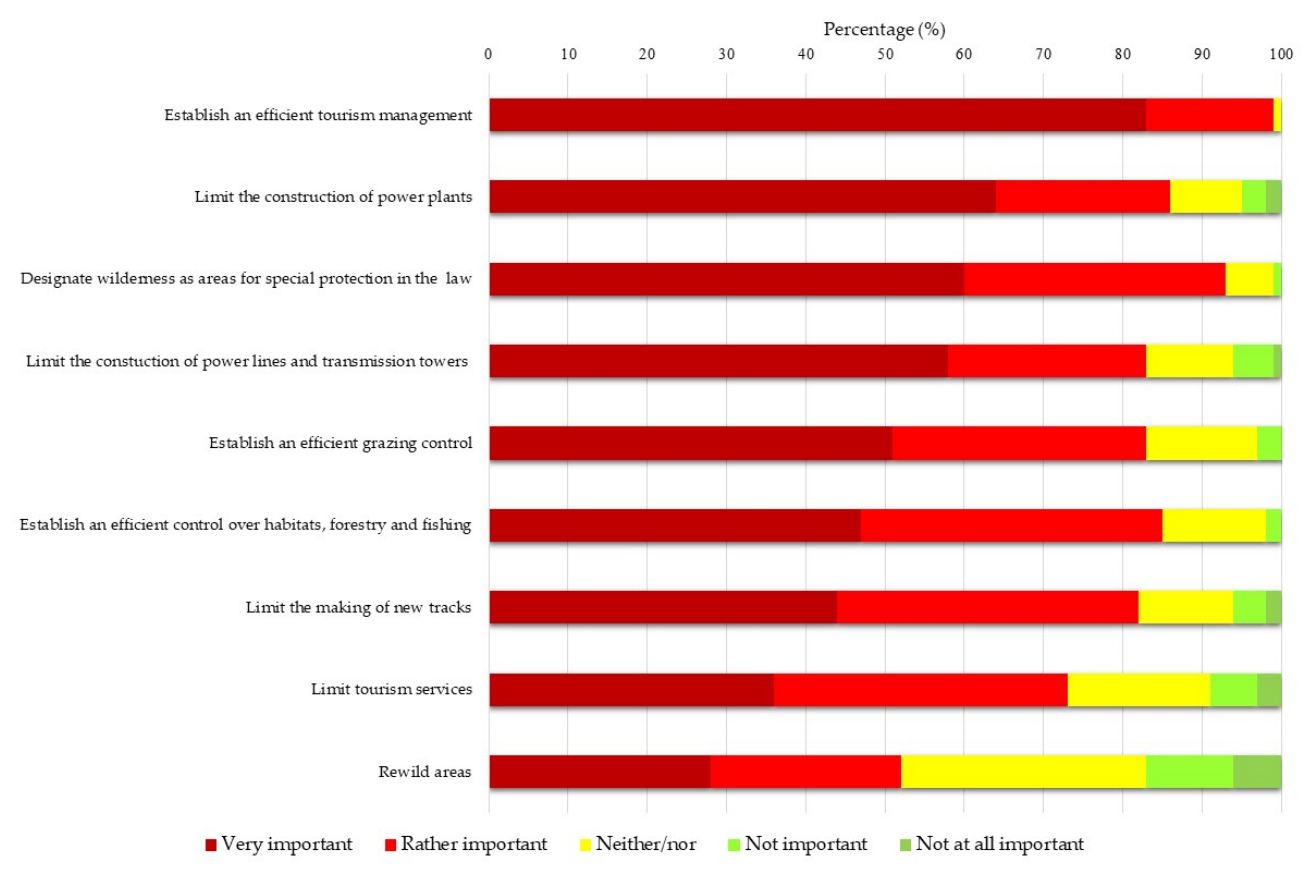

Figure 12. Important actions in order to conserve Icelandic wilderness.

Table 2. Principal component analysis of important conservation action.

\begin{tabular}{|c|c|c|}
\hline \multirow{2}{*}{ Variable } & \multicolumn{2}{|c|}{ Components } \\
\hline & 1 Restrictions & 2 Management \\
\hline Limit the construction of power plants & 0.84 & -0.05 \\
\hline Limit the construction of power lines and transmission towers & 0.79 & 0.12 \\
\hline Re-wilding areas & 0.70 & 0.24 \\
\hline Limit the making of new tracks & 0.65 & 0.38 \\
\hline Limit tourism services & 0.54 & 0.23 \\
\hline Designate wilderness as areas for special protection in the law & 0.54 & 0.41 \\
\hline Establish an efficient control over habitats, forestry and fishing & 0.21 & 0.85 \\
\hline Establish an efficient tourism management & 0.12 & 0.49 \\
\hline Establish an efficient grazing control & 0.11 & 0.87 \\
\hline
\end{tabular}

Bold numbers represent numerical values higher than 0.5 . 
To obtain a figure of the Icelandic public with respect to the purism scale that hitherto has mainly been used to categorize tourists, the survey respondents were asked about the importance of several elements when they travel in Icelandic wilderness. This specific question has been used in multiple studies in Iceland to categorize types of tourists according to the aforementioned purist scale [12,34]. The results demonstrate that the respondents find most important to not see traces of off-road driving, to enjoy tranquility, and experience pristine nature. They, moreover, regard being able to walk in nature without seeing anthropogenic infrastructure or signs of tourism to be important. Markings at places of interests, marked walking routes, pedestrian bridges, and campsites with facilities are elements that weigh less for Icelanders (Figure 13). Hence, the respondents place a considerable emphasis on the pristine appearance of nature in wilderness and to be able to experience tranquility and quietude, while they find infrastructure, such as rest areas and designed footpaths, less important. However, the responses underlying the pattern obtained from the principal component analysis identified three components which altogether explain $63.8 \%$ of the total variance in the answers, reflecting Icelanders' tolerance towards anthropogenic infrastructures when it comes to outdoor recreation (Table 3). The first factor explains about $33 \%$ of the total variance of the variables. Respondents scoring high on this component are in general of the opinion that good infrastructure and services are important. They prefer constructed and maintained hiking trails, bridges over rivers, organized campsites and picnic places, marked hiking routs and marked places of interest. The second strongest factor represents a desire to experience pristine nature and it explains about $20 \%$ of the total variance. For respondents scoring high on this component, it is important to be able to enjoy nature in solitude and tranquility, relying on themselves in challenging situations, and to have no visible signs of off-road driving. The third factor reflects attitudes characterising those who appreciate freedom, such as being able to camp anywhere they want.

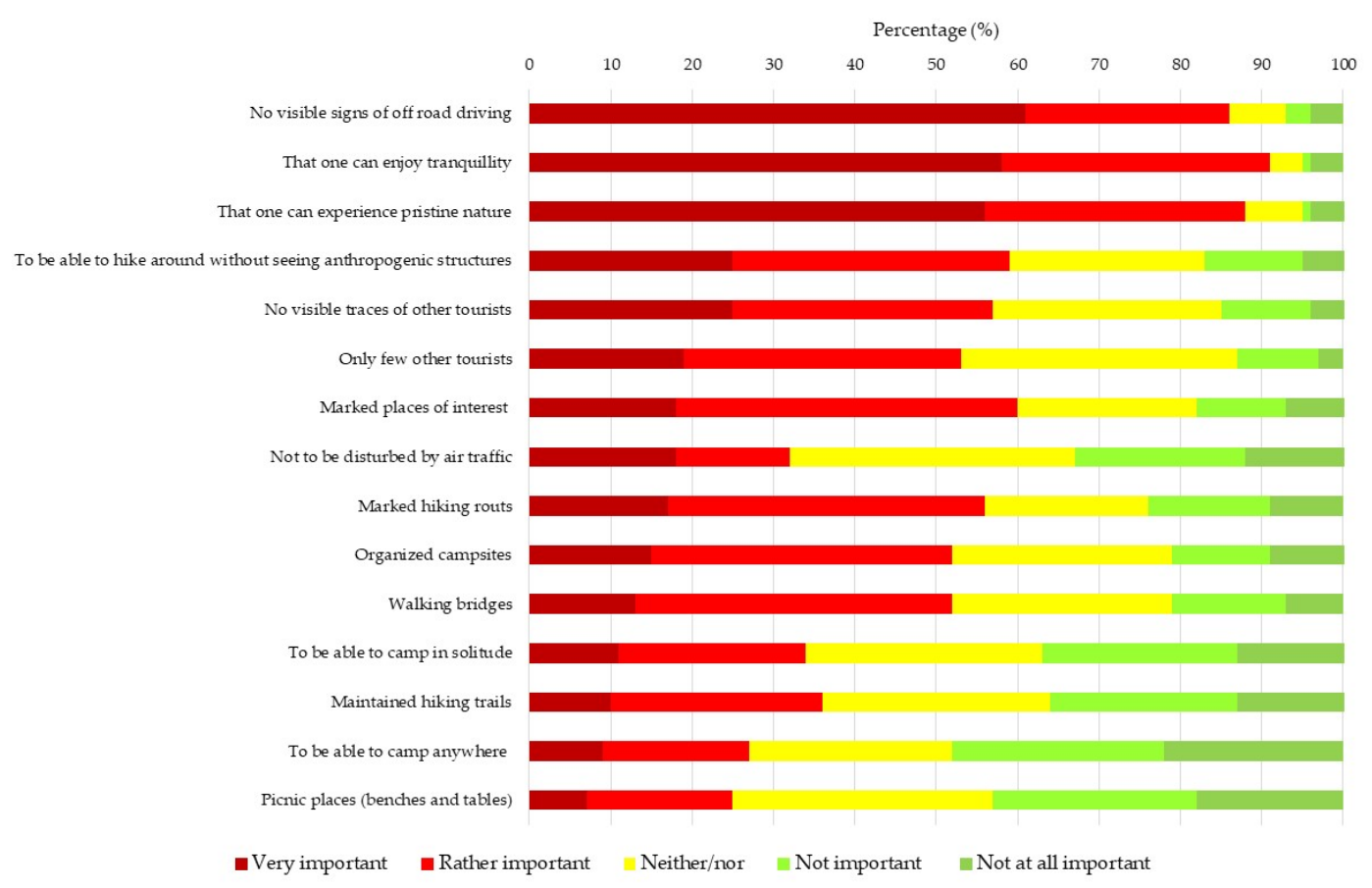

Figure 13. Elements that Icelanders consider important when they travel through Icelandic wilderness. 
Table 3. Principal component analysis of important elements in wilderness.

\begin{tabular}{|c|c|c|c|}
\hline \multirow{3}{*}{ Variable } & \multicolumn{3}{|c|}{ Components } \\
\hline & 1 & 2 & 3 \\
\hline & Good Infrastructure and Service & Pristine Nature & Freedom \\
\hline Walking bridges & 0.85 & 0.08 & 0.07 \\
\hline Maintained hiking trails & 0.82 & -0.03 & 0.01 \\
\hline Marked hiking routs & 0.80 & 0.18 & 0.02 \\
\hline Marked places of interest & 0.78 & 0.22 & 0.05 \\
\hline Picnic places (benches and tables) & 0.75 & -0.10 & 0.17 \\
\hline Organized campsites & 0.73 & 0.23 & -0.15 \\
\hline No visible signs of off-road driving & 0.28 & 0.75 & -0.03 \\
\hline That one can enjoy tranquility & 0.21 & 0.80 & 0.06 \\
\hline That one can experience pristine nature & 0.15 & 0.84 & 0.00 \\
\hline No visible traces of other tourists & 0.09 & 0.72 & 0.19 \\
\hline To be able to camp in solitude & 0.06 & 0.18 & 0.88 \\
\hline Not to be disturbed by air traffic & 0.05 & 0.35 & 0.49 \\
\hline To be able to camp anywhere & 0.02 & -0.01 & 0.87 \\
\hline Only few other tourists & -0.04 & 0.61 & 0.22 \\
\hline $\begin{array}{l}\text { To be able to hike around without seeing } \\
\text { anthropogenic structures }\end{array}$ & -0.08 & 0.78 & 0.10 \\
\hline
\end{tabular}

Bold numbers represent numerical values higher than 0.5 .

The results from the principal component analysis corresponds with the analysis of the survey respondents according to the purism scale, which shows that over half of them (52\%) fall into the category of urbanists, less than $40 \%$ into the category of neutralists, under $8 \%$ of moderate purists, and less than $1 \%$ of strong purists (Figure 14). This is interesting as research into the composition of tourists in various nature destinations in Iceland $[12,45,46]$ shows that neutral tourists are the most numerous category, or over half of all tourists, while urbanists count for a quarter, and purists for one-fifth of tourists.

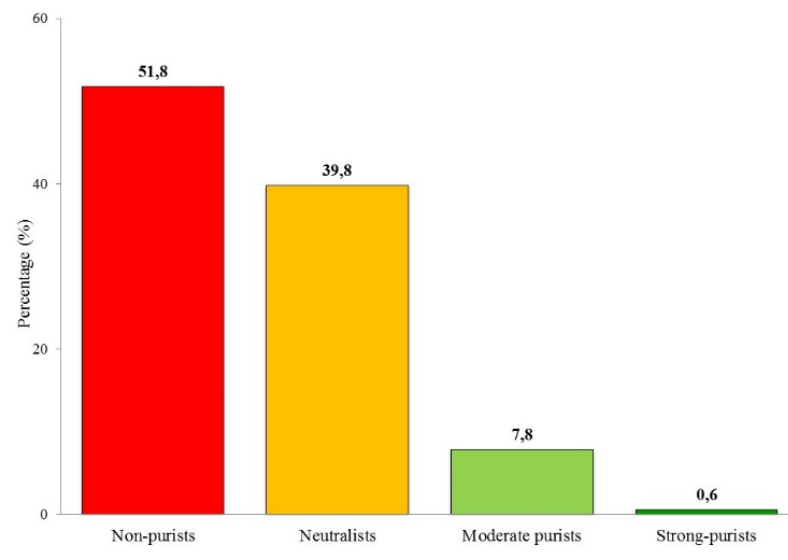

Figure 14. Icelanders categorized according to the purism scale.

\section{Discussion and Conclusions}

\subsection{Icelanders' Perception and Understanding of Wilderness}

Numerous studies (e.g., [18,47-50]) have shown that the landscape holds various 'layers of meaning', which contain a symbolic significance. That means that people can look at the same landscape and experience it differently. What the individuals perceive from the various information in the landscape depends on peoples' senses, as well as on what they consciously and unconsciously 
select to read from the landscape. That then depends on peoples' attitudes, knowledge and relation to the area [4]. Accordingly, whether people perceive an area as a wilderness is a selective practice in the sense that people see or tend to see what fits into their prior beliefs and image of an area. The Icelandic highlands have throughout the ages been more or less uninhabited as the small Icelandic population has mostly been distributed in the country's lowlands along the coastline. The highlands were for a long time very remote and difficult to access. Likewise, they were difficult to travel around because of their harsh and instable terrain and vigorous glacial rivers. A condition which created all kinds of rumors about supernatural beings, such as trolls, elves, ghosts and outlaws, living within the highlands, shaped their mysterious image [13] that still partly remains despite today's good accessibility and subsequently numerous travelers. The results from this study show that virtually all areas without permanent settlements, which reflect the uninhabited highland areas, are perceived as wilderness by the Icelandic public. This can most likely be explained by Icelanders historical relation to the previous condition of the highlands.

The results further show that for the general public in Iceland it is chiefly an open and vast landscape, uninhabited areas, and the absence of anthropogenic infrastructures, which bestow an area with the status of wilderness. Therefore, a vast and open landscape with few distinct landmarks, which is rather easy and safe to travel through, appeals more to Icelanders' understanding of wilderness than an area which is difficult and dangerous to cross and characterized by a formidable landscape, instability, and dissimilar yet conspicuous landmarks. Conversely, the latter characteristics are the attributes which appeal most to the Scottish public's perception of wilderness [41]. Moreover, it is notable that areas with natural vegetation cover appeal more to Icelanders' perception of wilderness than arid, unstable, and insecure areas. A possible explanation could be the fact that vegetated areas are rare in the Icelandic highlands and that such vegetated oases in the highlands have long been considered valuable by Icelanders and an attraction for highland explorers. However, what seems to unite the perception of Icelanders in areas which they perceive as wilderness are tranquility and quietude, which corresponds with international research $[1,16,51]$.

\subsection{The Value of Wilderness}

The results demonstrate that anthropogenic infrastructures generally have a negative impact on the value of wilderness according to the Icelandic public. The exceptions are remnants of human residence in the landscape, such as cairns, peat and stone walls, as well as old sheep herders' huts. This concurs with both domestic and international studies, which show that the perception towards new constructions is often more negative than that towards those that have historical connotations $[46,52]$. Accordingly, it appears that what is permissible in wilderness without decreasing their value depends on economy and trends of each era $[13,53]$. Still, new constructions are generally larger and thus more conspicuous in the landscape than smaller constructions, and as a result their impact is more negative. For Icelanders, the value of wilderness primarily lies in the opportunity to experience tranquility, quietude, and solitude in areas with simple and primitive infrastructure. Nature conservation also augments the value of wilderness. The results show however that the Icelandic public is somewhat tolerant towards anthropogenic infrastructures as regards outdoor recreation in the country's highlands, explaining the vast scope of the perceived wilderness covering all the country's central highlands despite numerous roads and tracks that currently exist in the highlands. Nonetheless, despite being mostly categorized as urbanists or neutralists, the majority of Icelanders still consider services, such as petrol stations, hotels, shops, restaurants, and diverse leisure services, along with energy production, to negatively impact the value of wilderness. This suggests that most Icelanders regard wilderness as a valuable asset, both from the economic perspective as well as from the cultural perspective, which underscores its uniqueness.

The central highlands of Iceland are one of the four main subjects in the Icelandic National Planning Strategy 2015-2026 [23], where emphasis is placed on their protection due to their importance for nature conservation and outdoor recreation. The strategy thus highlights that wilderness is significant 
for Icelanders and should be preserved. The strategy furthermore points out the importance of not decreasing the experience of wilderness and quality of nature in the central highlands, while it is stated that proper infrastructure for tourists should be promoted. This contains a certain paradox, one which is reflected in the perception of the Icelandic public towards wilderness, as they both wish to conserve pristine nature and use this resource for their own, and the country's, benefit. Wilderness has become one of Iceland's major tourist attractions $[34,54]$ and tourism has grown to be the country's largest export industry [55]. As such, wilderness is a valuable asset for Iceland. With more and more tourists visiting the Icelandic highlands the demand for tourism infrastructure gradually increases. It has been shown $[11,54,56]$ that if this demand is met by further infrastructure development, wilderness quality will be reduced and the composition of the types of tourist who visit the highlands is likely to change and accordingly affect Icelanders' wilderness experience. Therefore, it is of vital importance that infrastructure development for tourism and other economic activities in wilderness areas is based on a carefully planned framework, such as the recreation opportunity spectrum (ROS) $[57,58]$. Such a framework helps to clarify the complex relationship between experiences, activities and the amount of infrastructure and development that should be allowed at each destination to fulfil desired experiences and activities [59]. Hence, as it is not possible to please every tourist within each area, ROS emphasizes the uniqueness of each area and the importance fulfilling the wishes of those tourists who subscribe to the kind of tourism and experience that is appropriate within the area. In the Icelandic highlands, there are not many areas left that can be categorised as primitive non-motorized or semi-primitive non-motorized according to the strictest two categories of the ROS framework. Since the first cars were brought into the highlands in the early 20th century, roads and dirt tracks have formed an extensive network $[13,60,61]$, gradually increasing the accessibility of the highlands, and this has consequently reduced their remoteness. It is however of great importance to reserve the still remaining primitive and semi-primitive non-motorized wilderness areas within the highlands for strong purists whose satisfaction greatly decreases with increased infrastructure and services $[12,34,54]$. Thereby, the variety and uniqueness of tourism in Iceland would be decreased, and the tourism industry would subsequently be less competitive also in an increasingly competitive environment.

The Icelandic government is currently preparing the foundation of a national park in the central highlands of Iceland, which could become Europe's largest national park. Wilderness protection is one of its main motivations [5]. Part of the argument is that wilderness is a unique and valuable resource. It is therefore vital that the use of Iceland's wilderness is based on an ideology of sustainable development, which requires a holistic vision and an understanding of the causality between different influencing factors. The results from this research underpin that the future management of Icelandic wilderness remains a great challenge. An altered land use in the central highlands, and other uninhabited areas in Iceland, requires increased research and monitoring in order to enhance the understanding of the nature of these changes and its impact on wilderness perception. Otherwise it is not possible to grasp their essence and scope. This is supported by the Icelandic National Planning Strategy, which also mentions the importance of increasing the knowledge and understanding of how Icelanders experience wilderness. This research forms a part of such improvements, and emphasizes the importance of public perception as a critical variable in wilderness mapping.

Author Contributions: Conceptualization, R.Ó.; methodology, R.Ó. and A.D.S.; validation, R.Ó. and A.D.S.; investigation, R.Ó. and A.D.S.; resources, R.Ó. and A.D.S.; data curation, R.Ó. and A.D.S.; writing-original draft preparation, R.Ó.; writing-review and editing, R.Ó. and A.D.S.; project administration, R.Ó. All authors have read and agreed to the published version of the manuscript.

Funding: This research was funded by the Ministry for the Environment and Natural Resources and the steering committee for the Icelandic Master Plan for Nature Protection and Energy Utilization.

Acknowledgments: We wish to give thanks to the Ministry for the Environment and Natural Resources for its funding and to the expert committee two in the third phase of the Master Plan for their support. We would like to acknowledge Helgi Guðmundsson, expert at the University of Iceland's Social Science Research Institute for being in charge of distributing the questionnaire survey and for his help with data analysis, Jonathan Huck for his help with the Map-me analysis, Guðmundur Björnsson and Johannes T. Welling for their assistance with the setup of 
the photographs. Thanks are further given to our anonymous reviewers for valuable comments and suggestions which have led to significant improvements to this paper. Additional thanks are given to Guðrún Valdimarsdóttir for language correction.

Conflicts of Interest: The authors declare no conflict of interest.

\section{References}

1. Boyd, S.; Butler, R. Tourism and the Canadian National Park System: Protection, Use and Balance. In Tourism and National Parks: International Perspectives on Development, Histories and Change; Frost, W., Colin, M.C., Eds.; Routledge: London, UK, 2009; pp. 102-113.

2. Fredman, P.; Sandell, K. 'Protect, Preserve, Present'-The Role of Tourism in Swedish National Parks. In Tourism and National Parks: International Perspectives on Development, Histories and Change; Frost, W., Hall, M.C., Eds.; Routledge: London, UK, 2009; pp. 197-208.

3. Stankey, G.H.; Schreyer, R. Attitudes towards Wilderness and Factors Affecting Visitor Behavior: A State-of-Knowledge Review. In National Wilderness Research Conference: Issues, State-of-Knowledge, Future Directions; General Technical Report; Intermountain Research Station, USDA Forest Service: Ogden, UT, USA, 1987; pp. 246-293.

4. Hall, C.M.; Page, S.J. The Geography of Tourism and Recreation: Environment, Place, and Space, 4th ed.; Routledge: New York, NY, USA, 2014.

5. The Ministry for the Environment and Natural Resources. Hálendispjóðgarður: Tillögur Og Áherslur Pverpólitískrar Nefndar [National Park in the Central Highland: Proposal and Emphasis from Cross-Political Committee]; The Ministry for the Environment: Reykjavík, Iceland, 2019.

6. Statistics Iceland. Population. Urban Nuclei. Population by Urban Nuclei, Age and Sex 1 January 2011-2019. Available online: https://statice.is/statistics/population/inhabitants/municipalities-and-urbannuclei/ (accessed on 12 December 2019).

7. Ólafsdóttir, R.; Guðmundsson, H.J. Holocene Land Degradation and Climatic Change in Northeastern Iceland. Holocene 2002, 12, 159-167. [CrossRef]

8. Ólafsdóttir, R.; Schlyter, P.; Haraldsson, H.V. Simulating Icelandic Vegetation Cover during the Holocene. Implications for Long-Term Land Degradation. Geogr. Ann. 2001, 83, 203-215. [CrossRef]

9. Arnalds, Ó.; Pórarinsdóttir, E.F.; Metusalemsson, S.; Jónsson, A.; Grétarsson, E.; Árnason, A. Jarðvegsrof Á Íslandi [Soil Erosion in Iceland]; Landgræðsla ríkisins \& Rannsóknastofnun landbúnaðarins: Reykjavik, Iceland, 1997.

10. Ólafsdóttir, R.; Runnström, M. How Wild Is Iceland? Assessing Wilderness Quality with Respect to Nature Based Tourism. Tour. Geogr. 2011, 13, 280-298. [CrossRef]

11. Ólafsdóttir, R.; Sæpórsdóttir, A.R.; Runnström, M. Purism Scale Approach for Wilderness Mapping in Iceland. In Mapping Wilderness. Concepts, Techniques and Applications; Carver, S., Fritz, S., Eds.; Springer: London, UK, 2016; pp. 157-176.

12. Sæpórsdóttir, A.D. Tourism Struggling as the Wilderness Is Developed. Scand. J. Hosp. Tour. 2010, 10, 334-357. [CrossRef]

13. Sæpórsdóttir, A.D.; Hall, M.C.; Saarinen, J. Making Wilderness: Tourism and the History of the Wilderness Idea in Iceland. Polar Geogr. 2011, 34, 249-273. [CrossRef]

14. US Congress. Wilderness Act; Public Law 88-577, 78 Stat. 890 as amended; (16 U.S.C. 1131(note), 1131-1136); US Congress: Washington, DC, USA, 1964.

15. Icelandic Nature Conservation Act. No 60/2013; Ministry for the Environment and Natural Resources, Government of Iceland: Reykjavik, Iceland, 2013.

16. Lesslie, R.G.; Taylor, S.G. The Wilderness Continuum Concept and Its Implications for Australian Wilderness Preservation Policy. Biol. Conserv. 1985, 32, 309-333. [CrossRef]

17. Hall, C.M. Wasteland to World Heritage: Preserving Australia's Wilderness; Melbourne University Press: Carlton, Victoria, Australia, 1992.

18. Cronon, W. The Trouble with Wilderness; or, Getting Back to the Wrong Nature. In Uncommon Ground: Rethinking the Human Place in Nature; Cronon, W., Ed.; Norton \& Co.: New York, NY, USA, 1996; pp. 69-90.

19. Oelschlaeger, M. The Idea of Wilderness: From Prehistory to the Age of Ecology; Yale University Press: New Haven, CT, USA, 1991. 
20. Callicott, J.B. The Wilderness Idea Revisited: The Sustainable Development Alternative. In The Great New Wilderness Debate; Callicott, J.B., Nelson, M.P., Eds.; The University of Georgia Press: Athens, GA, USA, 1998; pp. 337-366.

21. Callicot, J.B. Contemporary Criticisms of the Received Wilderness Idea. In Wilderness Science in a Time of Change; Proceedings RMRS-P-15-VOL-1; Cole, D.N., McCool, S.F., Freimund, W.A., O'Loughlin, J., Eds.; U.S. Department of Agriculture, Forest Service, Rocky Mountain Research Station: Ogden, UT, USA, 2000; pp. 24-31.

22. The Ministry for the Environment and Natural Resources. Welfare for the Future. Iceland's National Strategy for Sustainable Development 2010-2013; The Ministry for the Environment and Natural Resources: Reykjavik, Iceland, 2011. Available online: https://www.government.is/media/umhverfisraduneyti-media/media/PDF_ skrar/Welfare-for-the-Future-Priorities-2010-2013.pdf (accessed on 12 December 2019).

23. National Planning Agency. Landsskipulagsstefna 2015-2026 Ásamt Greinargerð [National Planning Strategy 2015-2026]; National Planning Agency: Reykjavík, Iceland, 2016.

24. Ólafsdóttir, R.; Sæpórsdóttir, A.D.; Guðmundsson, H.; Huck, J.; Runnström, M. Viðhorf Og Upplifun Íslendinga Á Viðernum, Óbyggðum Og Miðhálendi Íslands [Icelanders' Attitude and Experience of Wilderness, Uninhabited Areas and the Central Highlands]; Institute of Life and Environmental Sciences, University of Iceland: Reykjavik, Iceland, 2016; p. 50.

25. Icelandic Nature Conservation Act. No 44/1999; Ministry for the Environment and Natural Resources, Government of Iceland: Reykjavik, Iceland, 1999.

26. Ólafsdóttir, R.; Runnström, M. Endalaus Víðátta? Mat Og Kortlagning Íslenskra Víðerna. Náttúrufræðingurinn 2011, 81, 57-64.

27. Tims, W. New Approaches for Wilderness Perception Mapping: A Case Study from Vatnajökull National Park, Iceland. Master's Thesis, University of Iceland, Reykjavík, Iceland, 2014, (unpublished).

28. Ólafsdóttir, R.; Sæpórsdóttir, A.D.; Runnström, M.C. Purism Scale Approach for Wilderness Mapping in Iceland. In Mapping Wilderness: Spatial Methods and Applications in Mapping and Modelling Wild Landscapes; Carver, S., Fritz, S., Eds.; Springer: Dordrecht, The Netherlands, 2016.

29. Taylor, V.F. Gis Assessment of Icelandic Wilderness from 1936-2010. Master's Thesis, University of Iceland, Reykjavík, Iceland, 2011, (unpublished).

30. Kliskey, A.D.; Kearsley, G.W. Mapping Multiple Perceptions of Wilderness in Southern New Zealand. Appl. Geogr. 1993, 13, 203-223. [CrossRef]

31. Lupp, G.; Höchtl, F.; Wende, W. Wilderness- a Designation for Central European Landscapes? Land Use Policy 2011, 28, 594-603. [CrossRef]

32. Van den Berg, A.E.; Koole, S.L. New Wilderness in the Netherlands: An Investigation of Visual Preferences for Nature Development Landscapes. Landsc. Urban Plan. 2006, 78, 362-372. [CrossRef]

33. Carver, S.; Evans, A.; Fritz, S. Wilderness Attribute Mapping in the United Kingdom. Int. J. Wilderness 2002, 8, 24-29.

34. Sæpórsdóttir, A.D. Preserving Wilderness at an Emerging Tourist Destination. J. Manag. Sustain. 2014, 4, 65-78. [CrossRef]

35. Komossa, F.; van der Zanden, E.H.; Verburg, P.H. Characterizing Outdoor Recreation User Groups: A Typology of Peri-Urban Recreationists in the Kromme Rijn Area, The Netherlands. Land Use Policy 2019, 80, 246-258. [CrossRef]

36. Porvarður, Á.; Ostman, D.; Adam Hoffritz, A. Kortlagning Vỉðerna Á Miðhálendi Íslands: Tillögur Að Nýrri Aðferðafræði [Wilderness Mapping in the Central Highlands: Suggestions for a New Method]; Hornafjörður Rannsóknasetur á Hornafirði, University of Iceland: Reykjavik, Iceland, 2017.

37. Sæpórsdóttir, A.D.; Ólafsson, R. Áhrif Hólmsárvirkjunar á Ferðamennsku og útivist [The Effect of the Proposed Power Plant Hómsárvirkjun on Tourism and Recreation]. In LV-2012-020, 115; Reykjavík Landsvirkjun and Orkusalan: Reykjavík, Iceland, 2012.

38. Groumpos, P.P. Fuzzy Cognitive Maps: Basic Theories and Their Application to Complex Systems. In Fuzzy Cognitive Maps. Studies in Fuzziness and Soft Computing Vol 247; Glykas, M., Ed.; Springer: Berlin/Heidelberg, Germany, 2010; pp. 1-22.

39. Huck, J.; Whyatt, D.; Coulton, P. Development and Application of a “Spray-Can” Tool for Fuzzy Geographical Analysis. In Proceedings of the GIS Research UK 21st Annual Conference, Lancaster, UK, 11-13 April 2012; Lancaster University: Lancaster, UK, 2013. 
40. Huck, J.J.; Whyatt, J.D.; Coulton, P. Spraycan: A Ppgis for Capturing Imprecise Notions of Place. Appl. Geogr. 2014, 55, 229-237. [CrossRef]

41. Wilson-Smith, E.; Crockett, J.; McCoard, S. Public Perception Survey of Wildness in Scotland; Cairngorms National Park Authority: Grantown-on-Sprey, UK; Scottish Natural Heritage: Inverness, UK, 2012.

42. Lesslie, R.G.; Maslen, M.; Canty, D.; Goodwins, D.; Shields, R. Wilderness on Kangaroo Island, National Wilderness Inventory: South. Australia; Australian Heritage Commission: Canberra, Australia, 1991.

43. Richard, V.M.; Lahman, M.K.E. Photo-Elicitation: Reflexivity on Method, Analysis, and Graphic Portraits. Int. J. Res. Method Educ. 2015, 38, 3-22. [CrossRef]

44. Loeffler, T.A. A Photo Elicitation Study of the Meanings of Outdoor Adventure Experiences. J. Leis. Res. 2004, 36, 536-556. [CrossRef]

45. Sæpórsdóttir, A.D. Planning Nature Tourism in Iceland Based on Tourist Attitudes. Tour. Geogr. 2010, 12, 25-52. [CrossRef]

46. Sæpórsdóttir, A.D. Ferðamennska Á Miðhálendi Íslands: Staða og spá um framtíðarhorfur [Tourism in the Central-Highlands. Current Situation and Future Expectations]; Institute of Life and Environmental Sciences, University of Iceland: Reykjavík, Iceland, 2012.

47. Vissering, J.; Sinclair, M.; Margolis, A. A Visual Impact Assessment Process for Wind Energy Projects; Clean Energy States Alliance: Montpelier, VT, USA, 2011.

48. Wyckoff, W. How to Read the American West: A Field Guide; University of Washington Press: Seattle, WA, USA, 2014.

49. Cosgrove, D.E. Social Formation and Symbolic Landscape; Croom Helm: London, UK, 1984.

50. Demeritt, D. What Is the 'Social Construction of Nature'? A Typology and Sympathetic Critique. Prog. Hum. Geogr. 2002, 26, 767-790. [CrossRef]

51. Higham, J.E.S. Sustaining the Physical and Social Dimensions of Wilderness Tourism: The Perceptual Approach to Wilderness Management in New Zealand. J. Sustain. Tour. 1998, 6, 26-51. [CrossRef]

52. Soini, K.; Pouta, E.; Salmiovirta, M.; Uusitalo, M.; Kivinen, T. Local Residents' Perceptions of Energy Landscape: The Case of Transmission Lines. Land Use Policy 2011, 28, 294-305. [CrossRef]

53. Benediktsson, K. ‘Ósnortin Víðerni', Ferðamennska Og Miðhálendi Íslands [‘Untouched Wilderness', Tourism and Iceland's Central Highland]. Landabréfið 2000, 16-17, 14-23.

54. Sæpórsdóttir, A.D. Managing Popularity: Changes in Tourist Attitudes to a Wilderness Destination. Tour. Manag. Perspect. 2013, 7, 47-58. [CrossRef]

55. Statistics Iceland. External Trade. Trade in Goods and Services. Selected Items of the Exports of Goods and Services 2013-2019. Available online: https://px.hagstofa.is/pxen/pxweb/en/Efnahagur/Efnahagur_ _utanrikisverslun_3_voruthjonusta_voruthjonusta/UTA05003.px (accessed on 8 February 2020).

56. Haraldsson, H.V.; Ólafsdóttir, R. Evolution of Tourism in Natural Destinations and Dynamic Sustainable Thresholds over Time. Sustainability 2018, 10, 4788. [CrossRef]

57. Sæprsdóttir, A.D.; Ólafsdóttir, R. Planning the Wild: In Times of Tourist Invasion. J. Tour. Res. Hosp. $2017,6$. [CrossRef]

58. Ólafsdóttir, R.; Sæpórsdóttir, A.D.; Noordhuizen, J.; Nijkrake, W. Sustainable Leisure Landscapes in Icelandic Rural Communities: A Multidisciplinary Approach. J. Manag. Sustain. 2018, 8, 54-64. [CrossRef]

59. Clark, R.N.; Stankey, G.H. The Recreation Opportunity Spectrum: A Framework for Planning, Management, and Research; US. Department of Agriculture-Forest Service: Portland, OR, USA, 1979.

60. Huijbens, E.H.; Benediktsson, K. Practising Highland Heterotopias: Automobility in the Interior of Iceland. Mobilities 2007, 2, 143-165. [CrossRef]

61. Huijbens, E.H.; Benediktsson, K. Geared for the Sublime: Mobile Images of the North. In Images of the North: Histories-Identities_Images; Jakobsson, S., Ed.; Rodopi: Amsterdam, The Netherlands; New York, NY, USA, 2009; pp. 117-130.

(C) 2020 by the authors. Licensee MDPI, Basel, Switzerland. This article is an open access article distributed under the terms and conditions of the Creative Commons Attribution (CC BY) license (http://creativecommons.org/licenses/by/4.0/). 